\title{
Urban Sprawl and its Impact on Urban Environment
}

\author{
Priyanka Dubey, Mr. Dilip Kumar \\ M.Tech (Environmental Engineering)and Mr. Dilip Kumar (Assistant Professor) \\ (Civil Engineering) Madan Mohan Malviya Engineering College Gorakhpur (U.P) India
}

\begin{abstract}
This Paper an attempt has been made to examine the urban sprawl of Gorakhpur City through the land sat Images. Remote sensing and GIS to analyze the urban sprawl mapping and detect changes of urban sprawl of Gorakhpur city through different year. Satellite data are found to be useful in mapping and quantifying the extent of urban area in different time periods. New urban region development growing largely towards north, north-west and south-west direction along the main transport route of the city. New urban development occurs mainly on vegetation and agricultural land.

This study provides a methodology for better estimation of urban growth and population using various land sat images with time. Geographical information system(GIS) and satellite images have been used in this study to provide spatial inputs and test the statistical model describing growth. This is useful for the urban planning in Developing Countries where land use data is not available regularly. GIS and Rescan help a lot in monitoring urban sprawl compared to Conventional technique
\end{abstract}

KeyWords: Urban Sprawl Pattern, Change Detection, Demographic Charactristics GIS, Gorakhpur City (U.P)

\section{Introduction}

Suburbs and the spreading of the city are called Urban sprawl. It spreading mainly in out skirts of the city and in rural or undeveloped areas, in the rural and undeveloped land which are situated in the out skirts of the city involves the construction of commercial building and residential areas. In the urban sprawl mostly people live in the nuclear or single family homes which are do their job in city and there transportation are through by private or own auto mobiles. For local environment and residents the over consequences of urban sprawl are positive and negative both. In our local economy urban sprawl play a vital role for its growth.

For positive and negative effect of our local and social economy urban sprawl is most important thing, which have the great effect in the respect of urban development. Those people who are live in city drive less for their requirement in comparison of those people which are live in sprawling areas. Generally air pollution are caused by urban sprawl an urbanisation which are part of development., It has also been linked to obesity since walking or bicycling usually are not viable commuting options for those commuting from the outskirts of a city into town.

Suburbs often involves the construction of residential and commercial buildings in rural areas or otherwise undeveloped land at the outskirts of a city. Most residents of typical urban sprawl neighbourhoods live in singlefamily homes and commute by car their own automobiles to their jobs in the city. Concerns over urban sprawl and its consequences have been raised and largely focus on negative consequences for residents and the local environment. On the other hand, some argue that "urban sprawl" illustrates positive growth of a local economy.

\subsection{Aims and Objectives}

- To analyze the urban sprawl of Gorakhpur city.

- To monitor urban land sat images from satellite and delineate Gorakhpur city boundary between 19752013

- To predict population and urban area growth for year (1975-2013)

\subsection{Data Base}

- Survey of India toposheets : 1:25000 scales

- Satellite Data: LANDSAT TM and LANDSAT ETM+ , LANDSAT MSS images (Source : http://glcfapp.glcf.umd.edu:8080/esdi/index.jsp )

- Census of India - Primary Census Abstract - 1975- 2013

\section{Study Area}

The Gorakhpur and its surroundings, which are taken as the study area, are spread over a territory of 3483.8 $\mathrm{km} 2(1345.1 \mathrm{sq} \mathrm{ml})$. This region is lie between latitude $26^{\circ} 46^{\prime} \mathrm{N}$ and longitude $83^{\circ} 22^{\prime} \mathrm{E}$. The region has a inhabitants in 2011 is 671,048; of which male and female are 353,550 and 317,498 respectively as per temporary reports of Census India. Although Gorakhpur city has residents of 671,048; its urban / metropolitan 
inhabitants is 692,519 of which 365,148 are males and 327,371 are females. Gorakhpur city is one of a medium sized, town of Uttar Pradesh State, India. In environmental terms, Gorakhpur city lies at latitude $26^{\circ} 46^{\prime} \mathrm{N}$ and longitude $83^{\circ} 22^{\prime} \mathrm{E}$ casing an area of about $3483.8 \mathrm{sq}$. $\mathrm{km}$. The development of urbanizing area along the most important transport arteries i.e. National Highway No.28 linking Lucknow-Barauni in Bihar. Gorakhpur is a city in the eastern division of the state, of Uttar Pradesh in India, close to the border with Nepal. It is the directorial headquarters of Gorakhpur District and Gorakhpur Division. It is also headquarter of North Eastern Railways. Involvement a border with the important region of Nepal and investment the headquarters of the busy North Eastern Railways makes, Gorakhpur a very active city.

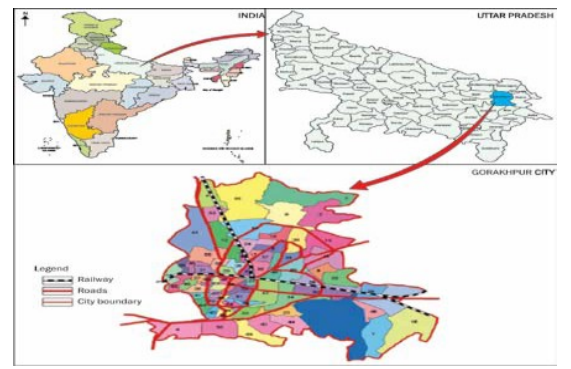

Fig-1.1 Location of study area: Gorakhpur segment, Source- http://www.lib.utexas.edu/maps/ams/india

\section{Result and Discussion}

Urban sprawl refers, to the area development of urban concentration further than what they have been. Urban spread out can be of three types-continuous, ribbons or check by road type. During 1975-1989 the building of city was underway and during 1975-89 many urban facilities were provide apart from large scale creation of residential accommodation, so that the inhabitants growth is four point in time less the urban area expansion. There is a whole absence of stipulation of areas for a numeral of urban activities such as engineering, institutional etc. which were not envisage.The population area in the year 1975 are 9.301715 square $\mathrm{km}$ and the population difference between 1975-1989 are 24.86 square km During 1989-2002 the population growth rate is four times the area enlargement, as during this era employees of various, departments came to inhabit in residential quarters, building for the government workers. The population growth area in the year 1989 are 34.16 squre $\mathrm{km}$ and the population difference between 1989-2002 are 23.22 square km During 2002-2006 the inhabitants growth and urban area enlargement are proportional. During 1974-81 the inhabitants growth rate has doubled compared to urban area growth. From 1981 onwards even though the population growth is proportional to urban area growth. The areal growth is constantly increasing where as the population growth is constantly decreasing. The population growth area in the year 2002 are 57.38 square $\mathrm{km}$ and the population difference between 2002-2006 are 14.01 square $\mathrm{km}$.The growth during 2002-2006 is more in outer periphery zone i.e. 7.5 $\mathrm{km}$ to $10.5 \mathrm{~km}$. From 2006-2013 tremendous rise in the built_up_from agricultural area, vegetation and open spaces. The city has its centre at the core areas. Though, the city initially evolve in rectangular shape on a network iron pattern from the middle, now it is rising largely towards north, northwest and southwest direction along the major transport route. The population growth area in the year 2006 are 71.39 square $\mathrm{km}$ and the population difference between 2006-2013 are 10.11 square $\mathrm{km}$. The population growth area in the year 2013 are 81.50 square $\mathrm{km}$

The Gorakhpur City Boundry and Layout of City Boundry year wise are given below

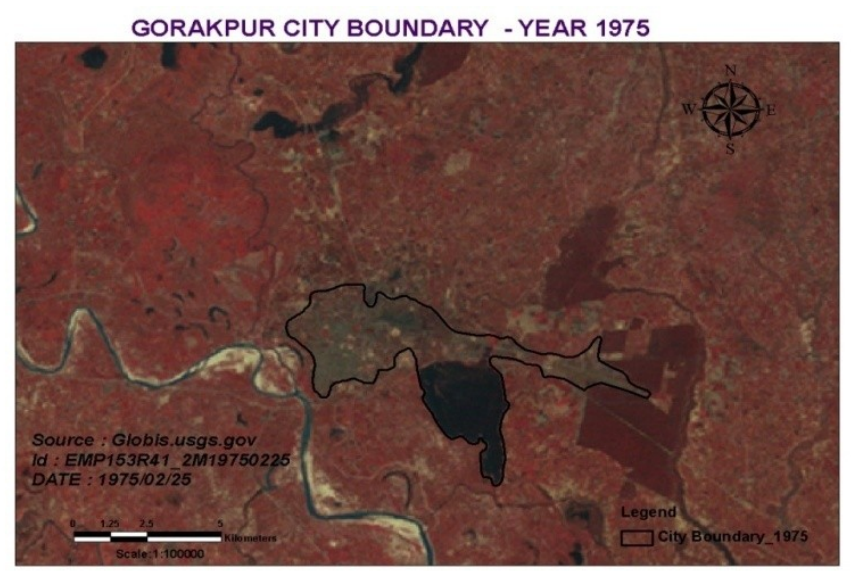



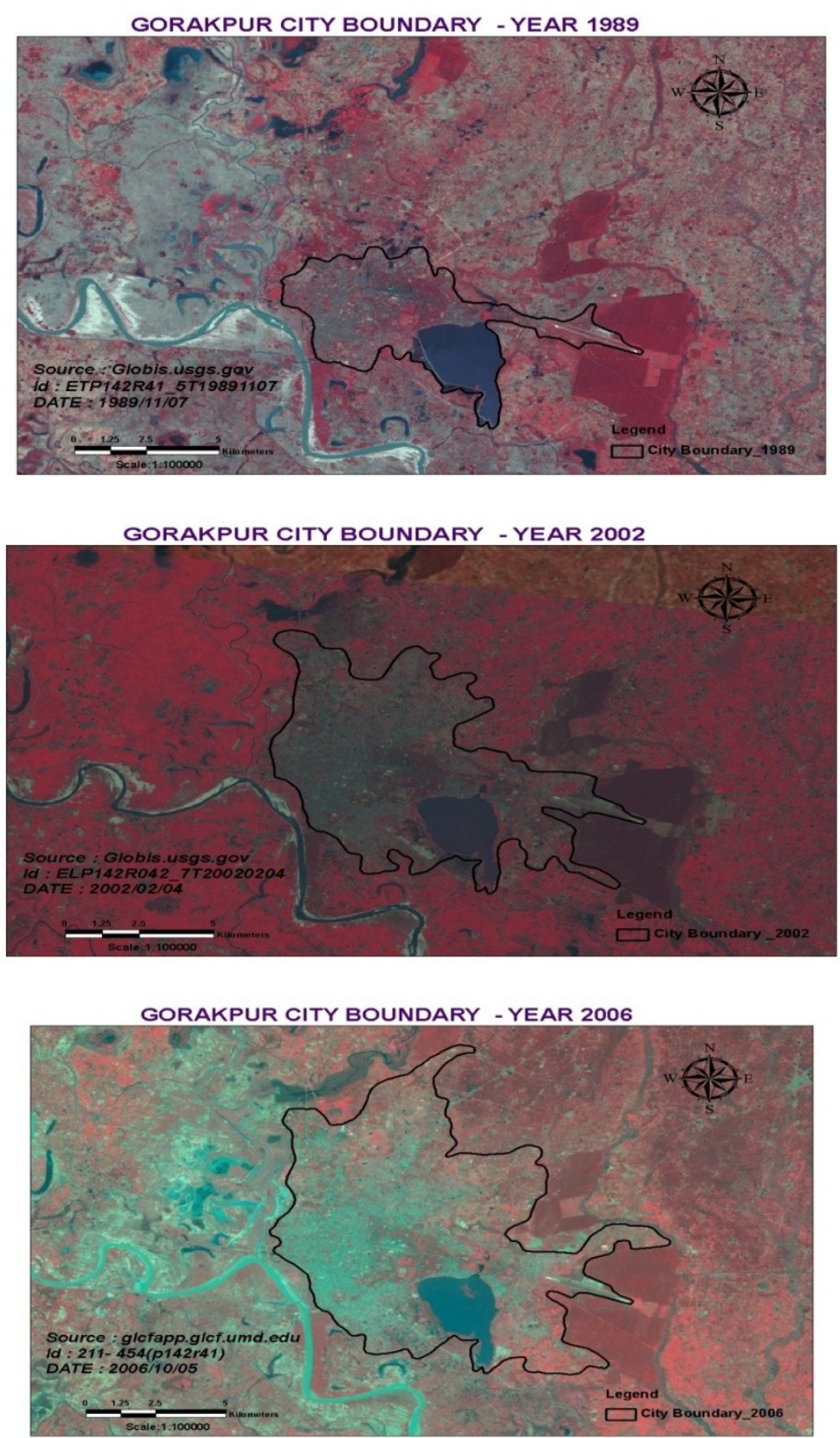

GORAKPUR CITY BOUNDARY - YEAR 2013

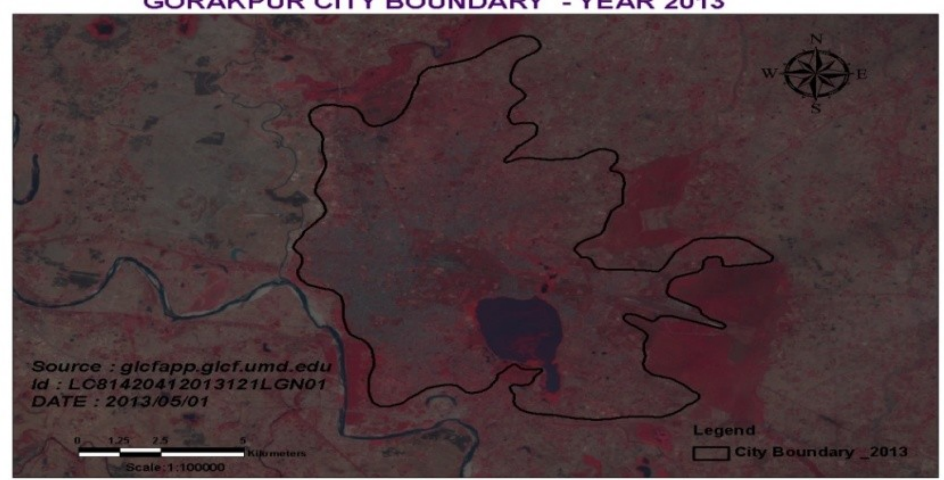




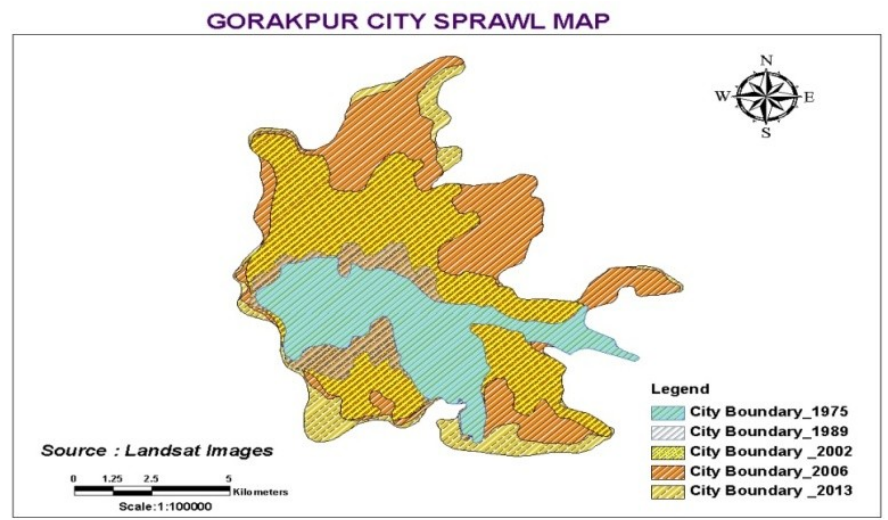

Gorakhpur City Population and City Area details are shown in Table No 1.1 which are given below

\begin{tabular}{r|r|r|r|r|r} 
S.No. & Years & $\begin{array}{c}\text { Total City } \\
\text { populati } \\
\text { on }\end{array}$ & $\begin{array}{c}\text { City Area } \\
\text { (Sq.km) }\end{array}$ & $\begin{array}{c}\text { Absolute } \\
\text { Area } \\
\text { Expansio } \\
\mathbf{n}\end{array}$ & $\begin{array}{c}\text { Area } \\
\text { expansio } \\
\text { n per } \\
\text { year }\end{array}$ \\
\hline 1 & 1975 & 261547 & 9.3 & & \\
\hline 2 & 1989 & 465953 & 34.16 & 24.86 & 1.775714 \\
\hline 3 & 2002 & 636336 & 57.38 & 23.22 & 1.786154 \\
\hline 4 & 2006 & 690876 & 71.39 & 14.01 & 3.5025 \\
\hline 5 & 2013 & 786321 & 81.5 & 10.11 & 1.444286 \\
\hline Table- 1.1 & \multicolumn{5}{|c|}{ Gorakhpur city Area and Population details }
\end{tabular}

Gorakhpur City population and Area Graph wise shown in the Fig.1.2 and 1.3

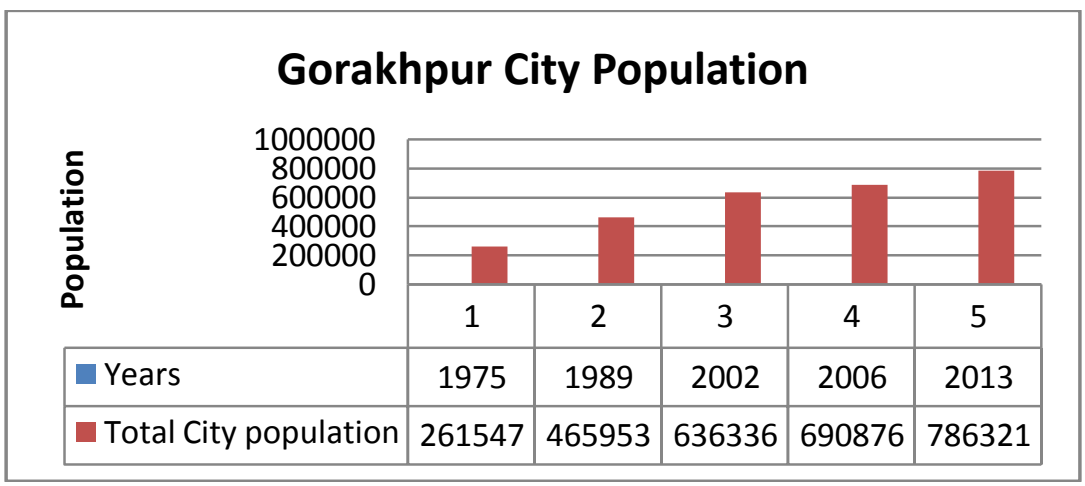

Fig-1.2 Shows city population over year wise

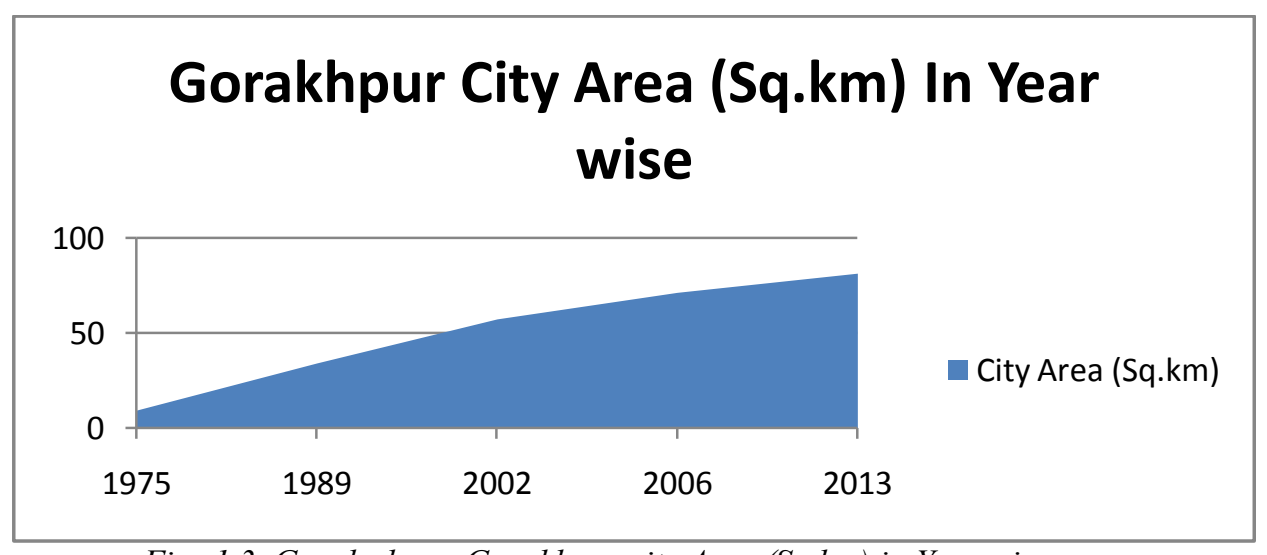

Fig- 1.3 Graph shows Gorakhpur city Area (Sq.km) in Year wise

In Year 1975 the Population of Gorakhpur city are 261547 in city area 9.3 sq.km. In Year 1989 the city population are 465953 in city area 34.16 sq.km In 2002 the population of the city 636336 in area 57.38 sq.km. In 2006 the population 690876 in city area 71.39 sq. km, in year 2013 the population of the city are 786321 in city area 81.5 sq. $\mathrm{km}$. 
In Gorakhpur City The graph between vehicular Stock and Year are shown in fig 1.4. In 1997 vehicle stock are 211023, in 2005- 320312 in 2010- 465350 in 2015 - 612212 . In 2020-886321

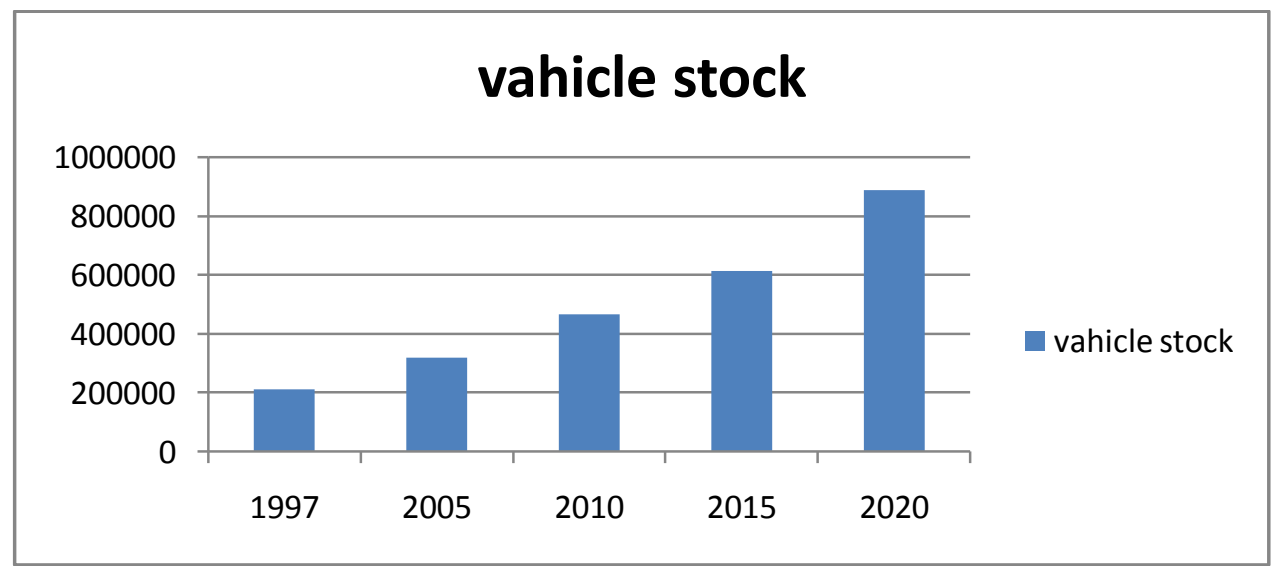

Fig-1.4 Graph exhibiting increase in vehicular Stock in Gorakhpur City

Estimates of the population in developing regions relying on different types of drinking water sources, 19902008 are shown in table 1.2

\begin{tabular}{|l|l|l|l|l|l|l|}
\multicolumn{2}{|c|}{ population (millions) } \\
\hline Facility Type & Urban & $\%$ & Rural & $\%$ & Total & $\%$ \\
\hline Piped on Premises & 1530 & $77 \%$ & 718 & $31 \%$ & 2248 & $53 \%$ \\
\hline public Tap/Stand pipe & 140 & $7 \%$ & 130 & $6 \%$ & 270 & $6 \%$ \\
\hline Borehole/ Tube well & 110 & $6 \%$ & 826 & $35 \%$ & 936 & $21 \%$ \\
\hline Rain water & 10 & $0 \%$ & 40 & $1 \%$ & 50 & $2 \%$ \\
\hline Dug Wells & 150 & $8 \%$ & 320 & $14 \%$ & 470 & $11 \%$ \\
\hline Springs & 20 & $0 \%$ & 130 & $6 \%$ & 150 & $3 \%$ \\
\hline $\begin{array}{l}\text { TankerTrucks/Small carts with } \\
\text { Drum }\end{array}$ & 38 & $2 \%$ & 10 & $0 \%$ & 48 & $1 \%$ \\
\hline Surface Water & 10 & $0 \%$ & 150 & $7 \%$ & 160 & $3 \%$ \\
\hline $\begin{array}{l}\text { Total } \\
\text { Bottled Water }\end{array}$ & 2008 & $100 \%$ & 2324 & $100 \%$ & 4284 & $\begin{array}{c}10 \\
\end{array}$ \\
\hline
\end{tabular}

Table-. 1.2 Estimates of the population in developing regions relying on different types of drinking water sources, 1990- 2008

\section{Conclusion}

This Paper amply demonstrates the use of remote sensing and GIS to analyze the urban sprawl mapping and detect changes of urban sprawl of Gorakhpur city through different year. Satellite data are found to be useful in mapping and quantifying the extent of urban area in different time periods. New urban region development growing largely towards north, north-west and south-west direction along the main transport route of the city. New urban development occurs mainly on vegetation and agricultural land. The above study provides a methodology for better estimation of urban growth and population using various land sat images with time. Geographical information system (GIS) and satellite images have been used in this study to provide spatial inputs andtest the statistical model describing growth. This is useful for the urban planning authorities in developing countries where land use data is not available regularly. GIS and remote sensing can help a lot in monitoring urban sprawl compared to Conventional techniques.

\section{Acknowledgement}

I feel a sense of deep self - satisfaction and a great experience of having accomplished my report entitled “URBAN SPRAWL AND IT'S IMPACT ON URBAN ENVIRONMENT”. For this I am pleased to express my profound gratitude to my report supervisor, Dr. R.K.SHUKLA (Associate Professor) Department of Civil Engineering, M. M. M. Engineering College, Gorakhpur, for his valuable guidance, intelligence suggestion, continuous motivation and moral support which helped me to complete this paper. 


\section{References}

[1]. Yeh, A. G. O., and Xia Li, 1996. Urban growth management in the Pearl river delta: an integrated remote sensing and GIS approach. ITC Journal, Special Habitat-II issue, 1996.

[2]. Tiwary, D. P. (2003), "Remote Sensing and GIS for efficient Urban planning in dia",GIS@development.net,http://www.gisdeveloment.net/application/urban/oveview/ma03224.htm, Map Asia conferences 2003, Urban Planning.

[3]. Barnes K. B., Morgan III J. M., Roberge M C., and Lowe S, 2001. "Sprawl development: Its patterns, consequences, and measurement".

[4]. Batty M., Xie Y., and Sun Z., 1999. "The dynamics of urban sprawl".

[5]. Epstein, J., Payne, K., and Kramer, E., 2002. "Technique for mapping suburban sprawl”. 